\title{
English majors' perceptions of their teachers' use of ICT in teaching of Listening-Speaking courses at Ho Chi Minh City Open University
}

\author{
Bui Thi Thuc Quyen ${ }^{1 *}$ \\ ${ }^{1}$ Ho Chi Minh City Open University, Vietnam \\ *Corresponding author: quyen.btt@ ou.edu.vn
}

\begin{tabular}{|c|c|}
\hline ARTICLE INFO & ABSTRACT \\
\hline $\begin{array}{l}\text { DOI:10.46223/HCMCOUJS. } \\
\text { soci.en.10.2.550.2020 }\end{array}$ & $\begin{array}{l}\text { This research investigated the perceptions of English majors } \\
\text { at Ho Chi Minh City Open University of the use of ICT by their } \\
\text { teachers in their Listening-Speaking classes. Twenty-eight out of } \\
\text { about } 700 \text { freshmen and sophomores who were studying the }\end{array}$ \\
\hline Received: June $17^{\text {th }}, 2020$ & in semi-structured interviews. The intervie \\
\hline Revised: December $14^{\text {th }}, 2020$ & then the qualitative data were analyzed through the process of \\
\hline Accepted: December $16^{\text {th }}, 2020$ & $\begin{array}{l}\text { reducing data, constructing themes, and drawing conclusions. The } \\
\text { findings indicated that in general, the students had positive } \\
\text { attitudes towards their teachers' use of ICT in teaching English } \\
\text { Listening-Speaking courses. Nonetheless, the interviews revealed }\end{array}$ \\
\hline Keywords: & the students' concerns and suggestions, which the school and the \\
\hline $\begin{array}{l}\text { students' perception, English } \\
\text { majors, English listening and } \\
\text { speaking subject, use of ICT }\end{array}$ & $\begin{array}{l}\text { teachers should take into account. These findings set the ground for } \\
\text { recommendations to teachers and administrators and for future } \\
\text { research presented at the end of the paper. }\end{array}$ \\
\hline
\end{tabular}

\section{Introduction}

Technology plays a crucial part in our modern society. With its rapid development, different technological tools have been invented and have remarkably changed the way we behave in all aspects of our life.

The use of technology has become a trend in the field of language education (Çakici, 2016). It is often referred to as information communication technology (ICT), a "diverse set of technological tools and resources used to transmit, store, create, share, or exchange information. [These] include computers, the Internet (websites, blogs and emails), live broadcasting technologies (radio, television and webcasting), recorded broadcasting technologies (podcasting, audio and video players and storage devices) and telephony (fixed or mobile, satellite, visio/videoconferencing, etc.)" (UNESCO, n.d.).

So far, ICT has proved its profound impact on improving the language teacher's professional performance. With ICT tools, teachers can prepare and conduct lessons more successfully. Specifically, teachers are able to attract more attention from learners; give clearer instructions to learners; expose learners to a variety of languages; engage learners with a wide range of learning activities; offer feedback on learners' works more effectively; enable learners to self-evaluate their language; and allow learners to create interactions not only with their classmates, the teachers, but also other people in the outside world (Chappelle, 2003; De Ramirez, 2010; Ilter, 2019; Kassim \& Zuraina, 2007; Kramsch \& Thorne, 2002; Lee, 2005; Rejeshwa, Sheilaja, \& Damodar, 2001; Reksten, 2000; Richardson, 2008; Wong \& Yang, 2017). As Akpabio and Ogiriki (2017) stated, ICT provides resources that transform teacher-centered and text-bounds 
classrooms into rich and student-focused learning contexts. More importantly, it presents students of different learning styles with opportunities for authentic input, output, and social interaction, which are supposed to be vital for communicative competence and language acquisition (Long, 1981, 1983, 1996; Swain, 1985, 1995, 2000; White, 1987).

Evidence has also shown that ICT has been integrated into listening and speaking lessons, and positive influences have been reported. Examples of the usefulness of ICT gadgets can be seen in Machmud and Abdula (2017)'s work where smartphones helped teachers to make use of class time more efficiently and reduce learner's anxiety in speaking; or in Puspani, Malini, and Indrawati (2013)'s study where portable MP3 with its convenience enhanced the teaching of listening. In addition, the Internet has been proved to be a powerful tool for many teachers to search for materials and create interactions for their learners. For instance, it gives assess to YouTube channels, news websites (Dang, 2011; Martinez, 2010), social media (Bahrani, 2011), and social networks in form of Web 2.0, Twitter, Facebook, Zalo, WhatsApp, etc. which present students with opportunities to practice the language and improve their speaking skills (Namaziandost \& Nasri, 2019; Pervaiz, 2016; Warschauer, 1995).

Despite the aforementioned benefits, challenges facing ICT integration have been pointed out. They are teachers' lack of experience and knowledge of using ICT in general or some particular tool; the constraints of the lesson content, time, and cost; insufficient physical capacity of classrooms; insufficient access to the resources; insufficient technical support (Bouziane, 2013; Cox, Preston, \& Cox, 1999; Yunus, Lubis, \& Lin, 2009). In addition, it should be noted that ICT "is not suitable for all learners in all situations and for all purposes, and may require some considerable learner training for effective use" (Livingstone, 2012, p. 12); it depends on students' level (Bahrani, Tam, \& Zuraidah, 2014); and maybe inhibited by teachers' lack of vision and by their belief of the burden it may bring (Dang, 2011). Moreover, in terms of communication, employment of social networks may bring about such disadvantages as dissemination of personal information, waste of time, misuse of the environment for unethical purposes, decrease in face-toface interaction, mistrust of communication, leading to addiction, information pollution, and security problems (Gülbahar, 2013).

Lawrence and Tar (2018), upon reviewing previous studies on factors influencing ICT use, proposed a conceptual model of ICT adoption and integration as follows:

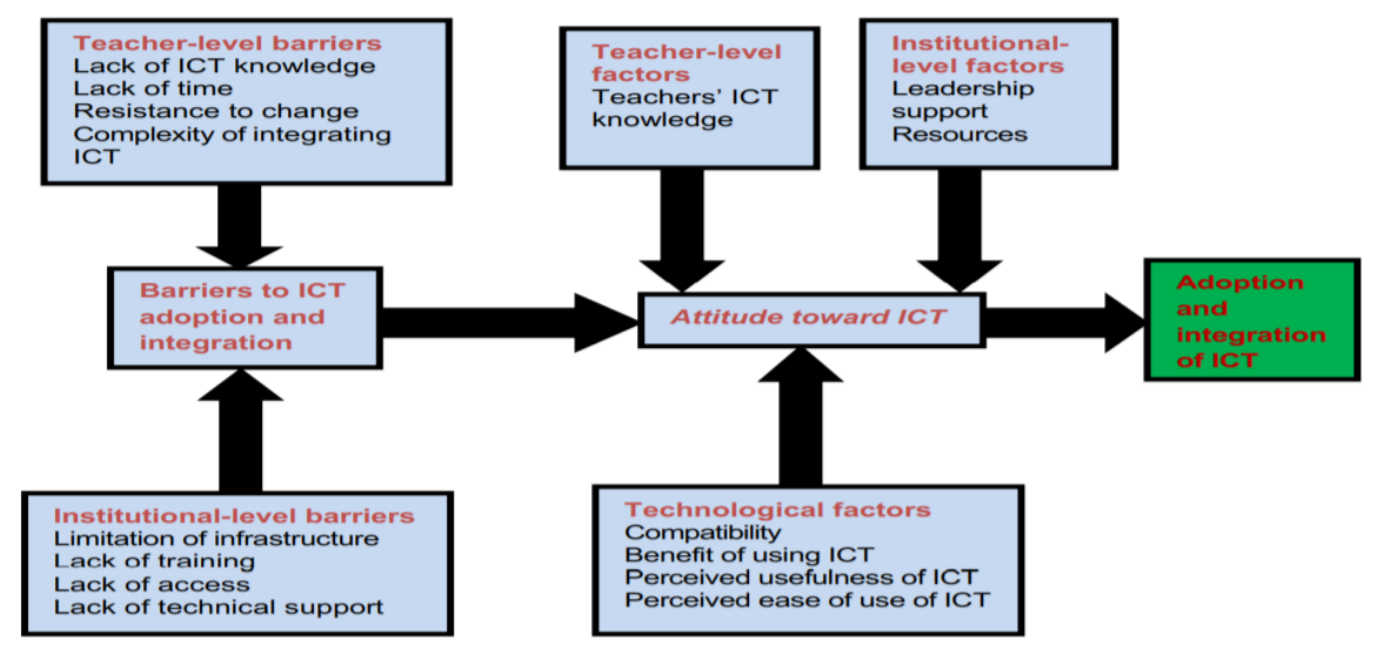

Figure 1. Conceptual model of ICT adoption and integration proposed by Lawrence and Tar (2018, p. 14) 
That model shows what matters is not only the tools but the infrastructure, the school policy, the context, the purpose, the training, and the people involved as well (Markauskaité, 2002). Thus, on the discussion about ICT use, it is advisable that different aspects rather than the tools themselves should be taken into consideration.

From the researcher's observation and the preliminary survey with 300 English majors who were studying the listening and speaking subject at the university, it is a fact that ICT has been employed in the Listening-Speaking course at Ho Chi Minh City Open University (hereafter, HCMCOU) though the tools and the degrees of use may be different. However, scarcely has any research been reported in detail on how ICT tools are used by the teachers in their classes. This study aimed to investigate the perceptions of HCMCOU students on their teachers' use of ICT in Listening-Speaking courses. Specifically, it focused on (1) what they perceived as the benefits of their teachers' use of ICT, (2) what their concerns about the use were, and (3) whether the use of ICT differed as regards the teachers' age range.

It was hoped that the findings would raise the teachers' awareness of the students' opinions on this matter so that they can have a suitable modification to enhance the quality of their teaching. It is also hoped that the findings would shed some light for the school and the faculty in charge to make appropriate policy to facilitate the employment of the tools, turning them into an asset to successful teaching and learning of listening and speaking.

\section{Methodology}

\subsection{Research design}

This study followed the exploratory design. According to the Library of Sacred Heart University (n.d.), "[an] exploratory design is conducted about a research problem when there are few or no earlier studies to refer to." As an investigation of English majors' perceptions of teachers' use of ICT in teaching Listening-Speaking courses at HCMCOU, the study tried to collect background information of the topic so that when using this study as one of their references, future research would have the possibility to be conducted.

\subsection{Research setting}

The research took place at HCMCOU, which is located in the South of Vietnam. The school was founded in 1990 and is the home of many multidisciplinary students. The Bachelor of Arts program is under the management of the Faculty of Foreign Languages. To ensure the students' communicative competence, six levels of Listening-Speaking courses are offered in six consecutive semesters starting from Semester 1. Q: Skill for Success Listening and Speaking (1 ${ }^{\text {st }}$ edition) published by Oxford University Press has been used as the core material, and completion of the online practice that accompanies the textbook accounts for $20 \%$ of the total scores of each level.

\subsection{Sampling method}

Twenty-eight students participated in the interview as a result of convenience sampling. The convenience sampling method selects the target subjects that are more readily accessible in terms of time, place, and the participants' willingness (Dörnyei, 2007).

About 700 English majors who were studying Listening-Speaking courses were divided by the school into 18 classes with 10 first-year and eight second-year groups. They were taught by nine teachers, who could be classified into three main age ranges: (1) the over 50s (two teachers); (2) the 40s (three teachers), and (3) the 30s and under (four teachers). At this stage, age was taken into account because it has been found to be a factor that affects ICT use (Czaja et al., 2006; Tacken, Marcellini, Mollenkopf, Ruoppila, \& Szeman, 2005). With that in mind, the researcher 
came up with 7 classes that were selected based on two criteria: (1) they represented those in charge by the teachers in the age ranges, and (2) they could be contacted easily by the researcher. Subsequently, the researcher went to the seven classes and asked for four volunteers from each class to participate in the semi-structured interviews.

\subsection{Instrumentation}

This study made use of semi-structured interviews to collect data. A semi-structured interview has been suggested as a tool that enables researchers to obtain in-depth information which seems to be difficult to gather when using a questionnaire (Schostak, 2006). The starting questions were: "In your opinion, what level do you consider yourself as in English speaking and listening? Excellent, good, average, or below average?"; "Do you use ICT when learning listening and speaking?"; "What are the ICT tools used in your Listening-Speaking lessons at HCMCOU"; "What do you think about the teachers' use of these tools in teaching you listening and speaking?" and "Do you think the facilities at the school or at home allow you to make full use of such ICT tools?"

\subsection{Data collection and data analysis}

The interviews were conducted face-to-face on a one-on-one basis. They were carried out in Vietnamese in order to free the students from the pressure of speaking English which might hinder their expression of ideas. The interviews were recorded and were transcribed. The transcripts were then analyzed, using manual coding suggested by Glaser (1992).

\section{Findings}

\subsection{ICT tools teachers use for Listening-Speaking courses}

Of 28 participants, all reported that their teachers used Powerpoint slides and audio of the core material. The teachers also employed e-dictionaries (4 students); videos ( 8 students); and other online resources, for example, exercises or documents relevant to the lessons (4 students). There are 4 students reporting the use of audio recording, and 4 students mentioning their teacher created a Zalo group for them to share learning experience in English. The students agreed that they did not have any difficulties using the ICT required by the teachers in different assignments.

The results showed all of the teachers integrated ICT at a certain level when teaching listening and speaking.

\subsection{The merits of their teachers' use of ICT in teaching Listening-Speaking courses}

The participants somehow acknowledged the benefits that the teachers' use of ICT brought about.

First, with the teachers' use of ICT, the lessons became more attractive, meaningful, and memorable to the students:

"My teacher often uses lesson slides and presents them, using a laptop and an overhead projector... Doing tasks like writing down keywords and looking at the pictures presented on the screen helps us memorize the lesson, makes the lesson livelier and attracts our attention" (Interviewee 10);

"Practically, teachers often use online dictionaries to instruct us on how to pronounce certain vocabulary in English, American, and Australian ways. And it helps us to understand more about the meaning of the word in each different communication situation" (Interviewee 3).

Second, the teachers' ICT use offered the students useful ways to make progress in their speaking. 
"The teacher in my class often has us write down a topic and record our reading. After that, we send the recording via email to him. This method of study can help me improve the way I organize my ideas and practice my pronunciation by listening to my voice over and over again. I can point out which part of my voice is not up to par. It also helps the teacher to identify the students' pronunciation ability" (Interviewee 4).

This allowed the students to improve their speaking competence thanks to more frequent feedback from the teachers and self-reflection on their oral production.

Furthermore, ICT use has promoted collaborative learning among the students, as mentioned by Interviewee 14, "The teacher from my class also created a Zalo group chat for the members of the class to share the experience and the lesson about English communication and I really like it".

\subsection{Students recommendations on teachers' use of ICT in teaching listening and speaking}

Eight students made suggestions on their teachers' use of ICT, emphasizing the need for interaction over ICT.

The students expressed their concerns about the use of ICT in Listening- Speaking classes, highlighting the insufficient interaction with regard to feedback, negotiation, and advice, which are supposed to be especially important for learning speaking. For Interviewee 1, "Lecturers should have more interaction with the students during the teaching process. If they just show the lesson on the slides and only focus on those slides but do not have any interaction with the students, it will be difficult for the students to study effectively." Also, Interviewee 10 said, “... we have to interact with each other, and practice speaking English with our friends and teachers. Therefore, we can point out the problems and advise each other immediately".

The students persisted that if ICT use did not promote interactions which enhance students' activeness and concentration on the lesson, it should be reconsidered: "In my opinion, the teachers should not abuse ICT because the class always needs interactions in order that students don't feel passive and focus more on the lesson" (Interviewee 19).

Another concern about the use of ICT in speaking classes is the lack of speaking activities beyond the classroom boundary:

"I would like to have out-of-class exercises where we have to talk to each other in English and complete tasks, just like people use English in reality...[The] time in class is not enough for speaking because a part of it is already devoted to listening practice" (Interviewee 25).

In addition, the students suggested that teachers should employ a wider variety of ICT tools so as to maintain their interest in the lesson: "... teachers can research new websites or applications. Using others rather than Youtube or Powerpoint slides... teachers will have more alternatives once the students get bored with one tool" (Interviewee 24).

In terms of listening skills, the students pointed out that the teachers should take into account the multiple levels of students in their classes and the mismatch between the students' listening ability and the level of difficulty of different audio texts. This will help the teachers to make use of ICT accordingly:

"Teachers need to invest more effort in selecting the listening audios for different levels because not every student in the class has the same level of listening ability. And teachers should let the students listen to the recording many times. They should have the script available for the students, too" (Interviewee 9). 
From the interviews, complaints and suggestions about the school's facilities which may influence the teachers' use of ICT in the classroom were recorded.

Eight students commented that sometimes they were not happy with the quality of the school's facilities:

"The thing that makes me quite annoyed is sometimes technical problems still happen. For example, the school Wi-fi is extremely slow, which makes the Internet connection in the classroom intermittent. There are occasions when the connection cable between the school projector and teacher's laptop is not compatible. This prevents the teacher from presenting the lesson slides and we need to ask the school's technicians to fix the problem, which wastes a lot of time of the lesson. I also noticed that the loudspeakers in some classrooms are often buzzing" (Interviewee 3).

In addition, 6 interviewees pointed out that the school should upgrade ICT devices:

"I think the school should invest money in upgrading ICT devices that are primarily used to support the students' study. Because we are living in this modern technology era, applying advanced technologies in learning and teaching is extremely necessary for improving the quality of the school's education" (Interviewee 3).

One interviewee even went further, saying that it would be better if the teachers were more proficient in ICT use: "The school needs to provide teachers with training workshops about using technological equipment and teaching software" (Interviewee 8).

To conclude this section, it is worth noting that though our main goal is to explore students' perception of the teachers' ICT use in teaching Listening-Speaking classes at HCMCOU, age was a criterion for sampling. However, no special pattern emerged from the students' responses in terms of teachers' age. Therefore, it is not evident that age is an influential factor for the use of ICT in Listening-Speaking courses at HCMCOU.

\section{Discussion}

As revealed from the interviews with students, teachers teaching Listening-Speaking courses at HCMCOU have made use of certain ICT tools, namely, Powerpoint slides, audio/video materials from the coursebook and from websites, Zalo, online dictionaries, and audio recorders to practice the language. This is in line with previous studies such as Dang (2011); Machmud and Abdula (2017); Martinez (2010); Namaziandost and Nasri (2019); Pervaiz (2016); and Warschauer (1995). These ICT tools are used maybe because they are free and user-friendly. Besides, since it was the teachers who chose those tools for their classes, though there is no clear evidence from the current study, it is possible that these types of ICT are aligned with the teachers' characteristics and their perceptions of the tools (Lawrence \& Tar, 2018; Markauskaité, 2002).

The students commented that those tools enhanced the quality of the lessons, notwithstanding there were concerns about inappropriate use or abuse of ICT tools, which may negatively affect communication in the classroom. Inappropriate use or abuse of ICT was asserted by Markauskaité (2002) and Lawrence and Tar (2018) to be the result of teachers' insufficient technological pedagogical knowledge and skills; and it may be true in this case.

It is clear from the students' opinions that while ICT can do many things, the utmost importance in the communication course is still oral interaction. At HCMCOU, the use of ICT tools has expanded interaction among class members; however, no evidence has been found about the use of ICT to create real contacts with people from the outside world. The absence of this ICT function may be attributed to the fact that interaction on social networks with strangers may expose the students to different risks (Gülbahar, 2013). Besides, monitoring students' work in online 
conversations is likely to take more time and increase the workload of teachers (Dang, 2011). Furthermore, a good internet connection, which is necessary for synchronous oral conversations may cause the extra cost for the students (Bouziane, 2013; Cox et al., 1999; Lawrence \& Tar, 2018; Yunus et al., 2009). For these reasons, the teachers may possibly have avoided using social networks for their students to carry on real communication with people outside their class.

Another point made by the students is that teachers should look for listening texts that are appropriate to students of low level. In reality, there is a variety of resources that the teachers can use as supplementary materials for their lessons (Bahrani et al., 2014). However, finding the ones with similar topics of the lessons may pose a challenge to the teachers as well as take much of their time (Gülbahar, 2013). This may cause a lack of variety of listening audio/video materials mentioned in the students' interviews.

Finally, the use of ICT of the teachers in this study does not vary with regard to teachers' age. Though different from Czaja et al.'s (2006) and Tacken et al.'s (2005), the result is in line with previous research such as Jegede's (2009), and Mahdi and Al-Dera's (2013). This may be attributed to the fact found in the interviews that the ICT tools made use by the teachers in this study are quite common and do not require special ICT skills or knowledge, which may be more challenging for the older teachers. Thus, in this study, age is not a factor that affects teachers' ICT use.

\section{Conclusion}

This paper has presented students' perceptions of their teachers' use of ICT in teaching Listening-Speaking courses at HCMOU. Though the convenience sampling method employed for data collection may not allow the findings to be generalized to broader teaching contexts, the information found can be of some value for teachers and administrators of schools that have similar characteristics.

In general, the students believe that the use of ICT by their teachers benefits their learning of listening and speaking. ICT makes the lessons more attractive and easy for the students and motivates them to study. Besides, the students suggest that so as to make the most of the tools, there should be regular maintenance and upgrading of ICT tools and the Internet connection as well as modification of ICT use. Most importantly, from the interviews, it is clear that there is a need for students' communication both in and outside the classroom because the students consider interactions opportunities for them to practice and to receive feedback on their language. Therefore, ICT use for out-of-class communication such as videos of students' interviews with foreigners (Bui, 2019) or chat groups for synchronous and asynchronous conversations (d'Eça, 2003; Mynard, 2002) should be considered good ideas. Additionally, collaboration in terms of sharing ICT resources, ICT knowledge and peer observation on ICT integration may help enhance to quality of ICT use without adding much to the teachers' workload. For that reason, together with activities to enhance teachers' technological pedagogical knowledge and skills, the Faculty of Foreign Languages is advised to encourage collaboration among teachers in this aspect.

In the current study, information about teachers' employment of ICT has been reported from the point of view of their students. Since the teachers themselves may also have their reasons behind the decisions on selection and use of ICT tools in their teaching, it is suggested that to fulfill the picture of teachers' use of ICT to teach listening and speaking at HCMCOU, teachers' perceptions are worth investigating. Furthermore, knowing what ICT tools teachers choose, and why and how they do that in a specific situation can also be an interesting topic; critical event studies can also be employed for future research. 


\section{References}

Akpabio, M. E., \& Ogiriki, I. B. (2017). Teachers use of Information and Communication Technology (ICT) in teaching English language in senior secondary schools in Akwa Ibom State. Equatorial Journal of Education and Curriculum Studies, 2(2), 28-33.

Bahrani, T., Tam, S., \& Zuraidah, M. (2014). Authentic language input through audiovisual technology and second language acquisition. SAGE Open, 4(3), 1-8. doi:10.1177/2158244014550611

Bahrani., T. (2011). Speaking fluency: Technology in EFL context or social interaction in ESL context. Studies in Literature and Language, 2(2), 162-168.

Bouziane, A. (2013). ICT integration in language teaching: Some challenges. The Tunisian English Language Teaching Forum, 7, 13-27. Retrieved June 9, 2020, from https://issuu.com/tarakbr/docs/forum_issue7

Bui, Q. T. T. (2019). An investigation into students' attitudes towards an out-of-class communicative task. In T. X. L. Nguyen, C. M. H. Huynh, T. T. Q. Bui, \& M. T. Mai (Eds.), Proceedings of the $7^{\text {th }}$ OpenTESOL international conference - Innovation and inspiration: Building the future of language education (pp. 153-170). Ho Chi Minh City, Vietnam: Ho Chi Minh City Publishing House of Economics.

Çakici, D. (2016). The use of ICT in teaching English as a foreign language. Participatory Educational Research (PER), 4, 73-77.

Chappelle, A. C. (2003). English language learning and technology. Amsterdam, Netherlands: John Benjamins Publishing Company.

Cox, M., Preston, C., \& Cox, K. (1999). What factors support or prevent teachers from using ICT in their classrooms? Paper presented at the British Educational Research Association Annual Conference, University of Sussex, Brighton Brighton, UK.

Czaja, S, J., Charness, N., Fisk, A. D., Nair, S. N., Rogers, W. A., \& Sharit, J. (2006). Factors predicting the use of technology: Findings from the center for research and education on aging and technology enhancement. Psychology and Aging, 21(2), 333-352.

d'Eça, T. A. (2003). The use of chat in EFL/ESL. The Electronic Journal for English as a Second Language, 7(1). Retrieved June 6, 2020, from http://www.tesl-ej.org/wordpress/issues/ volume7/ej25/ej25int/

Dang, T. X. (2011). Factors influencing teachers' use of ICT in language teaching: A case study of Hanoi University, Vietnam. Paper presented at International Conference: ICT for Language Llearning $4^{\text {th }}$ edition, Florence, Italy.

De Ramirez, L. L. (2010). Empower English language learners with tools from the web. Thousand Oaks, CA: Corwin Press, Inc.

Dörnyei, Z. (2007). Research methods in applied linguistics. New York, NY: Oxford University Press.

Glaser, B. G. (1992). Basics of grounded theory analysis. Mill Valley, CA: Sociology Press.

Gülbahar, Y. (2013). Social networks from higher education students' perspective. Anadolu Journal of Educational Sciences International, 3(2), 22-32.

Ilter, B. G. (2019). Effects of technology on motivation in EFL classrooms. Turkish Oline Journal of Distance Education-TOJDE, 10(4), 136-158. 
Jegede, P. O. (2009). Age and ICT-related behaviours of higher education teachers in Nigeria. Issues in Informing Science and Information Technology, 6, 771-777.

Kassim, H., \& Zuraina, A. (2007). The use of ICT in the implementation of Student-Centred Learning (SCL). Internet Journal of E-language Learning \& Teaching, 4(1), 15-31.

Kramsch, C., \& Thorne, S. L. (2002). Foreign language learning as a global communicative practice. In D. Block \& D. Cameron (Eds.), Globalization and language teaching (pp. 83100). New York, NY: Routledge.

Lawrence, J, E., \& Tar, U. A. (2018). Factors that influence teachers' adoption and integration of ICT in teaching/learning process. Educational Media International, 55(1), 79-105. doi:10.1080/09523987.2018.1439712

Lee, C. (2005). Web-based teaching and English language teaching: A Hong Kong experience. Hong Kong: The University Press of Hong Kong.

Library of Sacred Heart University. (n.d.). Organizing academic research papers: Types of research designs. Retrieved June 6, 2020, from https://library.sacredheart.edu/c.php? $\mathrm{g}=29803 \& \mathrm{p}=185902$

Livingstone, S. (2012). Critical reflections on the benefits of ICT in education. Oxford Review of Education, 38(1), 9-24.

Long, M. (1981). Input, interaction and second language acquisition. Annals of the New York Academic of Sciences, 379, 259-278. doi:10.1111/j.1749-6632.1981.tb42014.x

Long, M. (1983). Native speaker/non-native speaker conversation in the second language classroom. In M. Clarke \& J. Handscombe (Eds.), On TESOL'82 (pp. 104-120). Washington, DC: TESOL.

Long, M. (1996). The role of the linguistic environment in second language acquisition. In W. Ritchie \& T. Bhatia (Eds.), Handbook of second language acquisition (pp. 413-468). New York, NY: Academic.

Machmud, K., \& Abdulah, R. (2017). Using smartphone-integrated model of teaching to overcome students' speaking anxiety in learning. English as a Foreign Volume, 6(9), 1-11. doi:10.18533/journal.v6i9.1249

Mahdi, H. S., \& Al-Dera, A. S. (2013). The impact of teachers' age, gender and experience on the use of information and communication technology in EFL teaching. English Language Teaching, 6(6), 57-67. doi:10.5539/elt.v6n6p57

Markauskaité, L. (2002). Information technology implementation: Analysis theoretical methods and frameworks. Informatics in Education, 1(1), 111-128.

Martinez, S. G. (2010). Using web resources to support teachers and students with the teaching and practice of listening comprehension. Emcuentro, 19, 20-31.

Mynard, J. (2002). Introducing EFL students to chat rooms. The Internet TESL Journal, 8(2). Retrieved June 10, 2020, from http://iteslj.org/Lessons/Mynard-Chat.html

Namaziandost, E., \& Nasri, M. (2019). The impact of social media on EFL learners' speaking skill: A survey study involving EFL teachers and students. Journal of Applied Linguistics and Language Research, 6(3), 199-215.

Pervaiz, S. (2016). The advantages and risks of using social networking in higher education in Pakistan. In T. Issa, P. Isaias \& P. Kommers (Eds.), Social networking and education. 
Llecture notes in social networks (pp. 83-97). Cham, Switzerland: Springer International Publishing.

Puspani, I., Malini, N., \& Indrawati, N. (2013). The application of ICT to enhance students' listening. Paper presented at 11th Asia TEFL International Conference: Englishes Across Asian Contexts: Opportunities and Challenges, Ateneo de Manila University, Philippines.

Rejeshwa, M., Sheilaja, P., \& Damodar, G. (2001). IT evolution, globalization and the teaching of English. New Delhi, India: Atlantic Publishsers and Distributors.

Reksten, L. E. (2000). Using technology to increase student learning. Thousand Oaks, CA: Corwin Press Inc.

Richardson, W. (2008). Blogs, podcasts, and other powerful tools for the classroom. Thousand Oaks, CA: Corwin Press Inc.

Schostak, J. F. (2006). Interviewing and representation in qualitative research projects. New York, NY: Open University Press.

Swain, M. (1985). Communicative competence: Some roles of comprehensible input and comprehensible output in its development. In S. Gass \& C. Madden (Eds.), Input in second language acquisition (pp. 235-253). Rowley, MA: Newbury House.

Swain, M. (1995). Three functions of output in second language learning. In G. Cook \& B. Seidlhofer (Eds.), Principle and practice in applied linguistics: Studies in honour of H. G. Widdowson (pp. 125-144). Oxford, UK: Oxford University Press.

Swain, M. (2000). Output hypothesis and beyond: Meditating acquisition through collaborative dialogue. In J. Lantolf (Ed.), Social cultural theory and second language learning (pp. 97114). Oxford, UK: Oxford University Press.

Tacken, M., Marcellini, F., Mollenkopf, H., Ruoppila, I., \& Szeman, Z. (2005). Use and acceptance of new technology by older people: Findings of the international MOBILATE survey "Enhancing mobility in later life". Gerontechnology, 3(3), 126-137.

UNESCO. (n.d.). Information and communication technology. Retrieved June 9, 2020, from http://uis.unesco.org/en/glossary-term/information-and-communication-technologies-ict

Warschauer, M. (1995). Virtual connections: Online activities and projects for networking language learners. Honolulu, HI: University of Hawaii Second Language Teaching and Curriculum Center.

White, L. (1987). Against comprehensible input: The input hypothesis and the development of L2 competence. Applied Linguistics, 8, 95-110.

Wong, G. K., \& Yang, M. (2017), Using ICT to facilitate instant and asynchronous feedback for students' learning engagement and improvements. In S. C. Kong, T. L. Wong, M. Yang, C. F. Chow \& K. H. Tse (Eds.), Emerging practices in scholarship of learning and teaching in a digital era (pp. 289-209). Singapore: Springer Nature Singapore Pte Ltd.

Yunus, M. M., Lubis, M. A., \& Lin, C. P. (2009). Learning via ICT: Uses, challenges and issues. WSEAS Transactions on Information Science and Applications, 6(9), 1453-1467. 